\title{
SIMPLE PATENT AND DIFFERENCE PATENTS
}

\author{
Edri wahyudi \\ 155100022 \\ Fakultas Komputer, 448757172 \\ edriwahyudi.student@umitra.ac.id
}

\begin{abstract}
Patent is an exclusive right granted by the State to the inventor of the results of his invention in the field of technology, which for a certain period of time carries out his own invasion or gives his consent to other parties to implement it. (Republic of Indonesia Law No. 14 of 2001, Article 1, paragraph 1)

A Simple Patent is any invention in the form of a new product or tool and has practical utility values due to its shape, configuration, construction or components

An invention is considered new, if at the time of the application for the patent the invention is not the same or not part of the prior art. Patent rights are territorial, that is, binding only in certain locations. Thus, to obtain patent protection in several countries or regions, a person must submit a patent application in each of these countries or regions.
\end{abstract}

Keywords: Simple Patents and Patents

\section{A. INTRODUCTION}

Patent is an exclusive right granted by the State to the inventor of the results of his invention in the field of technology, which for a certain period of time carries out his own invasion or gives his consent to other parties to implement it. (Republic of Indonesia Law No. 14 of 2001, Ps. 1, v. 1)

Meanwhile, the meaning of the Invention and Inventor (contained in the above definition, also according to the law, is):

- Invention is an Inventor idea that is poured into a specific problemsolving activity in the field of technology can be a product or process, or an improvement or development of a product or process. (Republic of Indonesia Law No. 14 of 2001, Ps. 1, v. 2)

- Inventor is a person who or some person who jointly carries out an 
idea poured into an activity that produces an invention. (Republic of Indonesia Law No. 14 of 2001, Ps. 1, v. 3)

The word patent comes from the English patent, which originally came from the word patere which means opening up (for public examination), and also comes from the term letter patent, which is a decree issued by the kingdom that gives exclusive rights to individuals and certain business actors. From the definition of the word patent itself, the patent concept encourages inventors to open knowledge for the betterment of society and instead, inventor gets exclusive rights for a certain period. Given that the patent does not regulate who has to do a patented invention, the patent system is not considered a monopoly right.

Subjects that can be patented. In general, there are three broad categories of subject matter that can be patented: processes, machines, and items produced and used. The process includes algorithms, business methods, most software, medical techniques, sports techniques and the like. The machine includes tools and apparatus.

Goods produced include mechanical devices, electronic devices and composition of materials such as chemicals, drugs, DNA, RNA, and so on. Specifically human embryonic stem (hES) cannot be patented in the European Union.

Mathematical truths, including those that cannot be patented.
Software that applies algorithms also cannot be patented unless there are practical applications (in the United States) or technical effects (in Europe). At present, the problem of software patents (as well as business methods) is still a very controversial subject. In the United States in several legal cases there, permitting patents for software and business methods, while in Europe, software is considered to be patented, although some inventions that use software can still be patented. Patents can relate to natural substances (such as substances found in the jungle) as well as drugs, medical treatment techniques and also genetic sequences, including controversial subjects. In various countries, there are differences in dealing with subjects related to this. For example, in the United States, surgical methods can be patented, but these patents get conflicting in practice. In view of the Hippocratic Oath principle, doctors must share their experience and expertise freely with their colleagues. So in 1994, the American Medical Association (AMA) of the House of Delegates filed an objection note against this patent application.

In Indonesia, the requirements for the findings to be patented are new (never disclosed before), contain inventive steps (unpredictable), and can be applied in industry. The protection period for an 'ordinary' patent is 20 years, while a simple patent is 10 years. Patents cannot be extended. To ensure that the 
researched technology has not been patented by other parties and is worth patenting, patent documents can be traced. There are some special cases of discovery that are not permitted to obtain patent protection, namely processes / products whose implementation is contrary to law, religious morality, public order or morality; methods of examination, treatment, treatment and / or surgery applied to humans and / or animals; and theories and methods in the fields of mathematics and science, namely all living things, except microorganisms, and important biological processes for the production of plants or animals, except for non-biological processes or micro-biological processes.

Patents are requested by the inventor by filling in a written Patent application in the relevant office. The applicant is given an understanding explaining how to make and use the invention under the rules of several legislation if it is unclear in his understanding of the usefulness of the invention. Patent applications may also consist of "claims". Claims confirm the discovery and embodiment of his invention so that applicants want clear rights.

For a patent to be granted, it will receive legal effect, the request must clearly fulfill legal requirements relating to patentability. If the patent usage is valid, most patent offices check applications to comply with the relevant Patentability law. If the application does not meet the requirements, the refusal is usually returned to their applicant or patent agent, who can respond to objections to try to deal with them and obtain a patent grant.

After being granted a patent, the subject in most countries for maintenance costs, generally updated every year, the US is an important exception.

In Egbert v. Lippmann, 104 US 333 (1881) (the "corset case"), the United States Supreme Court affirmed the decision that an inventor who had "truly thought of his rights for eleven years" by not applying for a patent could not get a patent at the time that. This decision is stipulated as rule 35 . which prevents an inventor from obtaining a patent if the invention has been used by the public for more than one year before applying for a patent. The requirements for the findings to be patented in Indonesia are new (never before disclosed), contain inventive steps (unpredictable), and can be applied in industry. The protection period for an 'ordinary' patent is 20 years, while a simple patent is 10 years. Patents cannot be extended. To ensure that the researched technology has not been patented by other parties and is worth patenting, patent documents can be traced. There are some special cases of discovery that are not permitted to obtain patent protection, namely processes / products whose implementation is contrary to law, religious morality, public order or morality; methods of examination, treatment, treatment and / or surgery applied to humans and / or animals; and 
theories and methods in the fields of mathematics and science, namely all living things, except microorganisms, and important biological processes for the production of plants or animals, except for non-biological processes or micro-biological processes. Indonesia is a large country with abundant mineral and energy resources. Unfortunately that potential has not been fully exploited. Most oil fields in Indonesia are still controlled by foreigners. The low oil technology we have is one of the factors why we have not been able to explore and extract oil from our own earth. Not only in the realm of fossil energy, our technological limitations are also seen in the processing and management of biomass (biofuel) based energy. For the biofuel sector, Indonesia is still practically still in place. Why is our energy problem so far behind other countries? One reason is the low level of new inventions in the field of patented energy technology that enable us to develop our own industry without the need to buy a foreign license. If we read the Patent News published by the Indonesian Ministry of Law and Human Rights, we can see that the application and acquisition of patents in the energy sector is very small. This is very concerning because patents are one indicator of whether a country can be classified as an industrial country or not. Actually, Indonesia has quite a lot of energy experts, but unfortunately not many patents or are interested in patenting their inventions for several reasons such as: the process is granted too long and costs a lot, worried that there are no buyers for the patents they have, while they have paid large in the management and maintenance, the patent management process seems complicated and prolonged, distrust of Indonesian patent institutions and so on Actually the procedure for making and managing patents is not as complicated or expensive as imagined, indeed to be granted it takes a long time because of various considerations such as checking whether in other countries there have been similar patents or not, and various other technical reasons. To help researchers and energy practitioners patent the results of their inventions, we describe in the following article the intricacies of patent regimes, such as patents, manufacturing requirements, registration fees, and the validity period of patents. What is presented here is not limited to patent inventions in the energy sector only, but also applies to patenting the results of non-energy inventions. Simple patent A Simple Patent is any invention in the form of a new product or tool and has practical utility values due to its shape, configuration, construction or components. Invention (invention) is the activity of solving certain problems in the field of technology, which can be in the form of processes or products of production or improvement and development of processes or 
products of production. Inventor is a person who individually or several people who jointly carry out activities that produce inventions. The patent holder is the inventor as the patent owner or the person who receives the right from the patent owner or another person who receives further rights from the person mentioned above, who is registered in An invention is considered new, if at the time of the application for the patent the invention is not the same or not part of the prior art. Patent rights are territorial, that is, binding only in certain locations. Thus, to obtain patent protection in several countries or regions, a person must submit a patent application in each of these countries or regions So, what is the difference between the types of patents? " Ordinary patents are given for inventions that are new, contain inventive steps, and can be applied in industry. While simple patents are given for each new invention, development of existing products or processes, and can be applied in industry. A simple patent is given for inventions in the form of products that are not only different in technical characteristics, but must have more practical functions / uses than previous inventions caused by their shape, configuration, construction or components which include tools, goods, machines, compositions, formulas, use, compound, or system. Simple patents are also given for inventions in the form of new processes or methods. The conclusion of this simple patent is that a finding is a development of previous findings that already exist but have more practical functions. Primarily, these findings can provide convenience in terms of use, for example in the design of a mobile phone. This simple patent can be a design finding that is slimmer and thinner so it is easy to carry compared to previous findings.

\section{B. CONCLUSION}

Patent is an exclusive right granted by the State to the inventor of the results of his invention in the field of technology, which for a certain period of time carries out his own invasion or gives his consent to other parties to implement it. (Republic of Indonesia Law No. 14 of 2001, ps. 1, v. 1)

A Simple Patent is any invention in the form of a new product or tool and has practical utility values due to its shape, configuration, construction or components.

An invention is considered new, if at the time of the application for the patent the invention is not the same or not part of the prior art. Patent rights are territorial, that is, binding only in certain locations. Thus, to obtain patent protection in several countries or regions, a person must submit a patent application in each of these countries or regions.

So, what is the difference between the types of patents? "

Ordinary patents are given for inventions that are new, contain 
inventive steps, and can be applied in industry.

While simple patents are given for each new invention, development of existing products or processes, and can be applied in industry.

A simple patent is given for inventions in the form of products that are not only different in technical characteristics, but must have more practical functions / uses than previous inventions caused by their shape, configuration, construction or components which include tools, goods, machines, compositions, formulas, use, compound, or system. Simple patents are also given for inventions in the form of new processes or methods.

The conclusion of this simple patent is that a finding is a development of previous findings that already exist but have more practical functions. Primarily, these findings can provide convenience in terms of use, for example in the design of a mobile phone. This simple patent can be a design finding that is slimmer and thinner so it is easy to carry compared to previous findings.

\section{ACKNOWLEDGEMENT University Of Indonesia University Of Mitra Indonesia Telkom University University Of Mellbourne Saitama University}

\section{REFERENCE (Based ISO 690)}

A. S. Putra And O. M. Febriani,
"Knowledge Management
Online Application In Pdam
Lampung Province," In
Prosiding renference On Information
Conferencent
Technology And Business
(Icitb), 2018, Pp. 181-187.

A. S. Putra, O. M. Febriani, And B. Bachry, "Implementasi Genetic Fuzzy System Untuk Mengidentifikasi Hasil Curian Kendaraan Bermotor Di Polda Lampung," J. Sist. Inf. Dan Manaj. Basis Data, Vol. 1, No. 1, Pp. 21-30, 2018.

[3] O. M. Febriani And A. S. Putra, "Sistem Informasi Monitoring Inventori Barang Pada Balai Riset Standardisasi Industri Bandar Lampung," J. Inform., Vol. 13, No. 1, Pp. 90-98, 2014.

[4] Putra, Arie Setya. "2018 Artikel Struktur Data, Audit Dan Jaringan Komputer." (2018).

[5] Putra, A. S. (2018, July 17). Paperplain Fundamental Create Application With Borland Delphi 7.0 University Of Mitra Indonesia. Retrieved From Osf.Io/Pbrn9. 


\section{E. REFERENCE (Based APA)}

Putra, A. S., Aryanti, D. R., \& Hartati, I. (2018, November). Metode SAW (Simple Additive Weighting) sebagai Sistem Pendukung Keputusan Guru Berprestasi (Studi Kasus: SMK Global Surya). In Prosiding Seminar Nasional Darmajaya (Vol. 1, No. 1, pp. 85-97).

Sari, D. P., Febriani, O. M., \& Putra, A. S. (2018, November). Perancangan Sistem Informasi SDM Berprestasi pada SD Global Surya. In Prosiding Seminar Nasional Darmajaya (Vol. 1, No. 1, pp. 289-294).

Putra, A. S. (2018). Paperplain: Execution Fundamental Create Application With Borland Delphi 7.0 University Of Mitra Indonesia.

Putra, A. S., Sukri, H., \& Zuhri, K. Sistem Monitoring Realtime Jaringan Irigasi Desa (JIDES) Dengan Konsep Jaringan Sensor Nirkabel. IJEIS (Indonesian Journal of Electronics and Instrumentation Systems), 8(2), 221232.

Darmawan, A., Yuliawati, D., Marcella, O., \& Firmandala, R. (2016). Sistem Absensi dan Pelaporan Berbasis Fingerprint dan SMS Gateway. EXPLORE, 7(1).

Febriani, O. M., Wahyuni, T., \& Yusuf, S. (2017). DESIGN OF WEBSITE-BASED INFORMATION SYSTEM FOR EDOCUMENT ADMINISTRASI IN THE COMMUNITY SERVICE UNIT (A Case Study at Rajabasa District). INTERNATIONAL JOURNAL OF
COMPUTERS \& TECHNOLOGY, 16(7), 7010-7020.

Febriani, O. M., \& Wahyuni, T. (2017, October). PERANCANGAN SISTEM E-DOCUMENT ADMINISTRASI LOGBOOK PENELITIAN PADA UNIT LAYANAN DI BANDAR LAMPUNG. In Prosiding Seminar Nasional Darmajaya (Vol. 1, No. 1, pp. 187-194).

Febriani, O. M., \& Permadi, A. B. (2017). Implementasi Sistem Aplikasi Data Bimbingan dan Pelanggaran Siswa pada Sekolah Menengah Atas di Lampung Tengah dengan Metode Analisis dan Desain Sistem Terdistribusi (SSAD). EXPERT, 7(1).

Febriani, O. M., \& Ambarwati, L. (2015). PERANCANGAN APLIKASI PENGOLAHAN DATA PENJUALAN UKM KELANTING KHAS TELO DESA SIDOHARJO KECAMATAN JATI AGUNG KABUPATEN LAMPUNG SELATAN. Jurnal Teknologi Informasi dan Bisnis Pengabdian Masyarakat Darmajaya, 1(1), 77-95.

Febriani, O. M. (2015). Rancang Bangun Aplikasi Ecommercemenggunakan Freewebstore pada UKM Kelanting di Desa Sidoharjo Lampung Selatan. Prosiding Sembistek 2014, 1(02), 446-458. 